\author{
Katarzyna Gutkowska-Ociepa* \\ University of Silesia
}

\title{
AFTERPOP: \\ THE ALMOST PERFECT CONVERGENCE
}

\begin{abstract}
This paper focuses on one of the newest notions in Spanish literary theory created by Eloy Fernández Porta in his work Afterpop. La literatura de la implosion mediatica (2007). The theorist reaches for the aesthetical accomplishments of postmodernism, avant-pop and cyberpunk in order to analyze them in the context of the new artistic mentality from the beginnings of XXI century. Juggling a multitude of literary techniques and names from various cultural backgrounds such as W. S. Burroughs, Julián Ríos, David Foster Wallace, David Cronenberg or Michael Haneke, Fernández Porta searches for new criteria and new methods of recognizing the complexity and insights of intermediatic, multifaceted and polysemic, implosive "new literature".
\end{abstract}

Key words: afterpop, polysemic new literature, intermediatic texts, Eloy Fernández Porta

An error has been detected in your consciousness.

All source-code is corrupt. Continue?

OK

$(\ldots)$

The network is monitoring your Digital Being. Create alias?

OK

Mark Amerika, OK TeXtS

The notion of the Afterpop may seem to some as kind of a terminological provocation as, for instance, the postpostmodernism of Jürgen Habermas, yet, whilst used as a powerful tool in the erudite discourse of Eloy Fernández Porta (born in 1974), it becomes a handy metaphor and etiquette for

* Philology Department, University of Silesia, Bankowa 12, 40-007 Katowice, e-mail: katarzyna.gutkowska@us.edu.pl 
the recent tendencies in the contemporary narrative. One should note that the contemporary novel is considered quite frequently a synecdoche for the whole concept of literature in the framework of Porta's metaliterary reflexions.

According to his observations, in the last decades, plenty has changed in literature and its way of functioning in the society: the widened scope of the impact of the mass media, both verbal and non-verbal, enabled the transition from the postmodern "hypertext" to its latest upgraded version: "intermedial text". The changes went quite deep, since:

[The] unprecedented expansion of culture, made possible specifically by the exponential growth of technology, has changed the contours of the world: pop culture has not only displaced nature and "colonized" the physical space of nearly every country on earth, but (just as important) it has also begun to colonize even those inner, subjective realms that nearly everyone once believed were inviolable, such as people's memories, sexual desires, their unconsciousness. (...) In fact, this landscape has increasingly become less a literal territory than a multidimensional hyperreality of television lands, media "jungles" and information "highways", a place where the real is now a "desert" that is "rained on" by a ceaseless "downpour" of information and data; "flooded" by a torrent of disposable consumer goods, narratives, images, ads, signs, and electronically generated stimuli; and peopled by media figures whose lives and stories seem at once more vivid, more familiar, and more real than anything the artist might create. Adapting to this new conditions has been especially difficult for fiction, a print-bound medium that seems especially ill-suited for survival in the global village's electronic system of communication, with its bewildering proliferation of new lingos, databases, and 57 channels (soon expanding to 500). (McCaffery 1995: XIII-XIV)

The cited words come from 1995 and they do not approach the problem hitherto from a more intermediatic point of view that may be found in the Porta's proposal: as one can see, the track leads here "de la metaficción a los metamedia": from the metafiction to the metamedia, the type of texts based entirely on the notion of transgression and the necessity of overcoming formal limitations of the traditionally perceived novel (Humanes Bespín 2007). The genre that seems to be predestined to surrender to the demands of the intermedial poetics without any significant difficulty should be a short story, since:

[...] el relato breve, tradicionalmente, [...] siempre [...] había sido un objeto cultural desde luego inferior a la novela pero también sujeto a una perceptiva, a una normativa y unos principios más estrictos que los de la novela. Es por eso que a partir de los cuarenta con Borges y después de él con los posmodernistas norteamericanos algunos autores empezarán a coger este objeto literario de vanguardia, en un banco de pruebas y experimentación [...] el ciberpunk a prin- 
cipios de los ochenta llega en un momento en el que el cuento, al menos en la tradición norteamericana, ya se ha establecido como género de vanguardia [...] A partir de ahí, el uso de los nuevos medios técnicos, sea cuentos en la red, sea poemas en flash [...] son un factor de transformación dentro de la teoría del relato $[\ldots]$ a mí me parece más importante el tratamiento temático de las nuevas tecnologías en esos relatos, porque si se da un cambio en la concepción de literariedad suscitado por los nuevos medios eso afectará a toda literatura, y probablemente a ese nivel no haya distinción entre la teoría del relato y teoría de la novela. (Humanes Bespín 2007)

$[(\ldots)$ traditionally, a short story (...) had always been a kind of a cultural invention characterized by an obviously inferior status than a novel, nonetheless it was always submitted to the much stricter evaluation, structural norms and rules than the ones referring to the novel. That is why from the forties with Borges and - afterwards - with the American postmodernists, some authors would seize precisely that avant-garde literary object and try to experiment with it [...] Cyberpunk ${ }^{1}$ consolidates at the beginnings of the eighties, at a time when a short story, at least in the American tradition, had already gained a position of an avant-garde literary form [...] Since then, the use of the new technical devices, such as on-line story, poems in flash [...] becomes an important factor in the transformation of the theory of the short story [...] what seems most relevant to me is the way of handling the new technologies as a subject in these stories, for the reason that if there is a change in conceiving the notion of the literariness evoked by the new media, it should affect the whole literature and, therefore, there will be no difference as far as a short story or a novel is concerned. (Humanes Bespín 2007)²]

Even though the name "work of art" may sound quite odd, inadequate and exaggerated to the generation of Javier Marías, Enrique Vila-Matas \& Antonio Muñoz Molina in the context of "afterpop", for the intermediaticly oriented Fernández Porta - it is definitely self-evident. Another member of his coeval group, a novelist, physicist and the author of the "Nocilla Project", the novelistic trilogy and a documentary that completes the three collections: Nocilla Dream, Nocilla Experience, Nocilla Lab-Agustín

1 In the article, I define cyberpunk as: a literary current in fantasy, originated in the 1980s. Some theorists claim it began with the appearance of Neuromancer by William Gibson in 1984, the bible of the genre. Chief representatives, apart from Gibson, are Rucker, Sterling, Cadigan, Stephenson. The main feature of all cyberpunk works is the description of the interior of the computer network, the electronic reality, which - after Gibson - is called cyberspace. The relevant characteristic of the cyberpunk poetics is the principle "High tech, low life", according to which the main character's living standard is quite low (e.g. he lives in a shantytown) even though it's situated in the world of strongly developed technology. The elements of cyberpunk may be found in Polish fantasy as well: Dukaj, Ziemkiewicz and Wiśniewski. (Marecki 2003: 299, transl. K. G.)

2 All Spanish and Polish citations in the article were translated by myself, unless indicated otherwise. 
Fernández Mallo, speaking of the future of narrative genres, pointed out that a novel:

(...) pasará por un soporte "que albergue texto música, fotografía y vídeo, y conexión on-line a la Red, y que la novela será una composición de ese tipo, mucho más completa y compleja que el cine incluso." (Azancot 2010)

[will accept the support offered to the text by music, photography, video and a broadband, so that the novel will become a composition much more complex and congeneric, even more that cinema (Azancot 2010)]

His declaration sounds fairly powerful as his "Nocilla Project" encountered wide echoes in the literary world in Spain and has become a foundation for the minting of the generational name of authors appurtenant to the new aesthetics: "los nocilleros" or "los nocilla"

The fragmentary nature of his prose and the managing of the plot as a pretext form for toying with the polimorphic appetite increased the frequency of them being called "los fragmentarios". Fernández Porta and Fernández Mallo more than once have presented together "Nocilla Project" as well as their other avant- and afterpopesque proposals with the usage of multimedial presentations, fragments of movies, images with sonic background, live shows with live music, sometimes even all of it at the same time. Both of them also share a way of understanding the main features and the potential of literature as well as a conviction about the future popularity of the intertextually and intermediaticly enriched nouvelle (the short novel format). The ascertainment of the author of Nocilla Dream about the short-sightedness and the limitations of the writers who seem to be insufficiently pleased with the new model of the novel and the experimentation of the younger generation of story-tellers also strengthens the foundation for the openness of the afterpop to the newer, more functional and more courageous artistic solutions:

Hay personas que se creen los garantes o elegidos para salvaguardar un templo sagrado, tarea que, en realidad, nadie, salvo una perversa maquinita que hay en cerebro llamada Super Yo, les ha pedido. Y trasladan esa confusión al terreno moral, de sacerdote. La literatura para ellos es una moral que está siendo violentada. Un puritanismo como otro cualquiera. Nada nuevo bajo el sol. Lo triste es comprobar que hay gente que piensa que aquí no hay sitio para todos. Personalmente, me encanta que se edite literatura que nada tenga que ver con la mía, y cuanta más, mejor. Me parece un signo de buena salud. (Azancot 2010)

${ }^{3}$ Nocilla is a popular Spanish brand of chocolate \& hazelnut spread. 
[There are some people who consider themselves the chosen ones, who think that their obligation is to protect the temple, even though they were not asked to do this by anything else than the perverse machine in their brains called Super Ego. They transfer this specific disorientation to the morality sphere. The literature constitutes for them some kind of ethics that seems to be violated. Puritanism as any other. There's nothing new under the Sun. It's sad to know that there is no place for everyone. Personally, I love that there is the literature that's completely different than mine; the more dissimilar, the better. I think it's a sign of a good health. (Azancot 2010)]

The opposition: they-superannuated and us-the open-minded ones is significant, since it is supposed to be a foundation of the concept of afterpop in literature. Nonetheless, the openness of the authors born in the seventies derives from the diametrically opposite set of artistic points of reference. For the "nocilleros" the most relevant ground of relation is contemporary American literature with its autothematic and culture-centered dimension, television (especially the animated TV series such as The Simpsons or Family Guy), the popular and niche yet accessible music and movie productions based on the multidimensional and polymorphic way of conveying the artistic message (e.g. Funny Games by Michael Haneke, where the mentality of the characters, their hierarchies and values are reflected by the conscientiously chosen soundtrack which evokes the ensemble of the stereotyped associations (cf. Fernández Porta 2007: 46)).

Indicating that Enrique Vila-Matas, born in 1948 in Barcelona, one of the best and the most experimenting Spanish novelists at present, despite all the innovations is not a creator of the afterpopesque texts, Fernández Porta revealed that the americocentrism is one of the main features that differs Vila-Matas from the younger authors (Paris has already stopped being the artistic, nostalgically idealised cradle). Furthermore we do not find in the works by the author of Dublinesque the appetite inscribed in the afterpopesque standards of intensified fictional pretextuality, even more enhanced, intermediatic intertextuality, biographic transgression in the creation of the homo duplex nor, though handled cum grano salis, relation with specific science, revealed at the lexical and conceptual levels. In order to exemplify it all in praxis, one could allude to the short characteristic of a novel that has become a starting point for the "fragmentarios" or "afterpoppies":

Nocilla dream, que puede soportar sin pesadumbre la etiqueta indie, es una de las apuestas narrativas más arriesgadas de los últimos años. Proliferan en ella las referencias al cine independiente norteamericano, a la historia del collage, al arte conceptual, a la arquitectura pragmática, a la evolución de los PCs y a la decadencia de la novela. Agustín Fernández Mallo se fija en los outsiders del 
siglo XXI y sobre todo en la misteriosa conexión entre algunas vidas alternativas y globalizadas que transitan por escenarios de Serie B: rubias de burdel que sueñan con que algún cliente las lleve hacia el Este, ácratas que habitan en extrañas micronaciones, ancianos chinos adictos al surf, un argentino que vive en un apartahotel de Las Vegas y construye un singular monumento a Jorge Luis Borges... Todos ellos atrapados en la metáfora conductora de los desiertos y en la belleza del vacío. ${ }^{4}$

[Nocilla dream, which undoubtedly could be tagged with the indie label, is one of the freshest, daring and graceful novels of the last few years. It's full of references to the independent American cinema, to the history of collage, to the conceptual art, to the pragmatic architecture and to the decadence of the novel. Agustín Fernández Mallo concentrates on the outsiders of the $21^{\text {st }}$ century and especially on the mysterious connection between some alternative and global biographies that pass through the screenplays of Series B: the blonds from the brothel who dream about a client bringing them to the West, anarchists living in the weird micronations, the Chinese senior citizens addicted to surfing, an Argentinean who lives in an apart-hotel in Las Vegas and dedicates himself to the creation of a monument of Jorge Luis Borges... All of them trapped in the leading metaphor of the deserts and the beauty of the emptiness.]

The title of the article as well as the whole concept of the afterpopesque convergence derives from the mini-treatise Afterpop with the significant subtitle: La literatura de la implosión mediática (Berenice, Córdoba 2007) which concerns the intensified tendency of cumulating extra-literary elements in the interior of fictitious texts. It is a procedure that might be called precisely "mediatic implosion" and it begins to take its toll in the contemporary prose almost on a regular basis. Moreover, it is becoming more and more noticeable not only in the narrative, but also in literary criticism. All in all, the monograph of Fernández Porta is an elaborated, comprehensive, interpretative model of a contemporary work of fiction and, at the same time, a border form which contains the components of the literary criticism, the historical outline of the literary evolution, the theoretical-literary project and a socio-cultural analysis. It constitutes an unconventional, (post)postmodern, erudite and jocose meta-literary hybrid - the only thing missing seems to be an added movie, series of multimedia or even a soundtrack, in spite of the fact that an addition of this sort would not have been a completely new touch in the publishing industry. Sometimes editors decide to add a DVD with a documentary or an interview to the printed version of a book; like in the case of the collection of

4 The description of the essence of the Fernández Mallo's esthetics comes from the webpage of his publisher, Candaya press: http://www.candaya.com/nocilladream.htm. 
essays and reviews on Vila-Matas's books: Vila-Matas. Portátil (Vila-Matas. Portable or, translating it in a more figurative way, Vila-Matas. On the go) or they introduce a kind of soundtrack that is somehow supposed to accompany the main text (we can observe these tactics in the edition of an Italian essay-treatise by Alessandro Baricco Next. Sobre la globalización y el mundo que viene (Baricco 2002) where some parts have been graphically marked and singled out with a mini-title "bonus track" which then find its explanation in the closing part of the book).

While reading the considerations of Fernández Porta, it is hard not to get hold of an impression that in spite of the gladly adapted new style and the subject area related to the world of the new media, by means of reconciling the extra-literary and ultramodern with the concept of a novel, there is an intricate net of intertextual ties with the universal dimension of the novelistic tradition, especially the Spanish-language one: Julio Cortázar, Jorge Luis Borges or Carlos Fuentes. The new prose is full of tricks and strategies present in the works by the South American literary giants: the perchant for the argumental dissociation, the fragmentariness and the literary magic put in the context of everyday triviality and, also, the creation of the broken identity of " $\mathrm{I}$ ", the predilection of Borges for the re-production of the relation between the word and the reality as a foundation of the cognoscible world, the obsessive return of the motif of a book and the labyrinth, the lack of chronological linearity and - known e.g. from Aura by Fuentes - steering of a discourse towards "You", toying with the fictional truth and false, suppositions and the substantial fact, the corporeality and the intangibility - all of these elements and techniques find a reflection in the new, intermediatic, afterpopesque prose.

The prefix "after" is crucial, since "los poppies" (a name invented by Fernández Porta) belong to the other kind of artists: they do not consider themselves popcultural. The author of Eros. La superproducción de los afectos does not deny pop culture the right to scaling the heights of sublimation and exploratoriness, however - similarly to the high, academic postmodernism and its lower, beatnik, Borroughsian postmodernist equivalent Fernández Porta also differentiates two registers of pop and, therefore, he indicates that the afterpop was created by the more sophisticated version of pop culture, the one penetrating not only the superficial dimension of the individual's and collective existence in a mediatic reality, but also by the tradition of avant-pop that eulogizes the literature as a still powerful artistic tool. All of the fore-mentioned aspects created along the way the new narrative quality: afterpop. 


\section{The prior to afterpop style, avant-pop, may be described as:}

doing many kinds of art, mixing the mass culture with the avant-garde or its high register, amalgamating various disciplines and, particularly, the relation with the Internet. The avant-pop artist gladly does the recycling; his favourite creating method is sampling. Usually, the ultimate version of his works is a hypertext, he loves combinating the genres, for instance, the prose with a comic-like style. A piece of art made by an avant-pop artist is a collage of the audio, space and visual forms which show the notable understanding of television, advertisements, video games, clips and the computer programming structure. (Marecki 2010: 220) ${ }^{5}$

The after-pop artist is the one who adds to the avant-pop revelations the specific kind of self-consciousness according to which the avant-pop solutions are merely an overture to the toying with more complex and better developed (meta)media:

se sitúa en un espacio histórica y simbólicamente posterior: asume que la cultura de consumo tal y como se conoció a lo largo de la segunda mitad del siglo XX no sólo «está en ruinas» sino que, en cierto modo, es el pasado inmediato. En algunos casos llega incluso a asumir que se trata de «un clásico» al que se respeta pero se da muy por sentado - tan por sentado que va desapareciendo-. En este sentido, tal autor da el paso siguiente al que lleva la camiseta de Michael Jackson en broma: ahora no es sólo un icono, por importante que fuera, el que se postula como «pasado» y «fantasmal», sino una estética entera. «Ahora aparezco. Ahora desaparezco. Ahora aparezco para desaparecer y se me perdonarán, espero, ciertas vacilaciones a la hora de intentar promover algo parecido al orden luego de un permisivo caos de años». Estas palabras, con las que empieza el relato de Fresán Apuntes para una teoría del escritor, me parecen muy representativas de

5 One might also be interested in other Polish understandings of the avant-pop aesthetics, for instance, the one presented by Piotr Siwecki who concentrates his attention other aspects of the current:

Banalizm i avant-pop wyrażają wspólne dążenie pisarzy, którym jest nie tyle odnalezienie własnej dykcji jako skrajnie indywidualnego stylu, ile odnalezienie dykcji w bezstylowości kooperacyjnej, czy też raczej kooperacyjnej bezstylowości (eklektyzm, plagiaryzm). Copyright przestaje być sygnałem odrębności twórcy - staje się często kategorią opisującą doświadczenie określonej grupy społecznej, pokolenia, choć jednocześnie pozostaje sygnałem tęsknoty za indywidualizmem nieuwikłanym w konsumerystyczną machinę promocji. (Siwecki 2010: 238)

[Banalism and avant-pop express the common aim of the writers which is not finding their own diction as an utterly individual style but finding diction with a lack of cooperative style or, more likely, cooperative unstyliness (eclectism, plagiarism). The copyright stops being an indication of the distinctiveness of the author; it often becomes a category describing an experience by a specific social group, a generation, although it still constitutes a manifestation of yearning for individualism which puts the consumerisistic promotion machine aside. (Siwecki 2010: 238)] 
la posición en que se sitúa el escritor afterpop. Esta posición se define por una ironía inestable y reconocida que se pone de manifiesto en una serie de continuos deslizamientos entre distintas maneras de abordar el permisivo caos de años de la cultura de consumo. En algunos casos se trata de una actitud retro en la que se describe la cultura pop desde un supuesto futuro; en otros, encontramos un gesto engagé, como si se tratase de una causa que requiere de filiación. [...] el escritor afterpop aparece de manera simbólicamente violenta en esa cultura adoptando posiciones que la problematizan, como la del extranjero, el primitivo o el teórico, de la misma manera, también desaparece de ella, adoptando actitudes que la superan, como la del coolhunter. (Férnandez Porta 2007: 62-63)

[he situates himself in a posterior historical and symbolic space: he assumes that the culture of consumerism, conceived in the second half of the $20^{\text {th }}$ century, is not only in decay, but also - in a way - has become a recent past. In some cases the author even assumes that it concerns the classics as well: respected but treated quite indulgently - so indulgently that it seems to disappear. Thus, the author makes a step that indicates that the T-Shirt of Michael Jackson as a joke is not an icon, even though it's perceived as important, phantasmal and coming from the past, but a total concept of aesthetics. «I exist now. Now - I disappear. Now, I appear in order to disappear and, I hope, my doubts and dilemmas accompanying me while trying to recuperate some state similar to order after the chaos of the years will be forgiven». I find the opening lines from the story by Fresán Apuntes para una teoría del escritor very representative from the position where the after-pop artist situates himself. It is characterised by the recognisable, yet slightly unstable irony that reveals itself in a series of the permanent slides between various ways of handling the indulging chaos of the years of the culture of consumerism. In some cases it is some sort of retro attitude in which pop culture is described from the supposed future; in others, on may find an engagé gesture as if it concerned the matter that requires some kind of affiliation. [...] the after-pop writer appears in this culture in a symbolically violent way, adopting stances which somehow problematize it, as the one of a foreigner, a primitive or a theorist; sometimes he disappears in it as well, adopting attitudes that overpower it, like the one of coolhunter. (Férnandez Porta 2007: 62-63)]

While depicting the variety of pop, Fernández Porta uses a style that "coruscates" with the plentitude of images and the metaphorical-allegorical formulation of the high and low register of culture. The critic transmutes the analysis in a hard-edged, puckish rewriting of the story, evoking literary topoi, tales and the characters approved and easily recognised by the pop-society. Accordingly, we find here the absorption of a poet by the surreal Unicorn, starved to death by the group of poets immersed eagerly in watching the football on television ${ }^{6}$ and, thusly, we hear here the echoes

6 Fernández Porta uses a motif here which is present in a short story by Marvin Cohen: The Saving of Surrealism Marvina Cohena from 1973. Cf. Fernández Porta 2007: 222-223. 
of the mesianistic-redeeming concept of an intellectual, close to the idea of an individual sacrifice for the wellbeing of the masses. There also includes the tabloid's aesthetics, grotesque description of an affair between Mrs Avantgarde and Mr Pop in Paradise City, celebrating in the world of innovations and the technicist creative impulses that lead the artists astray. Pop seems to be here a character of a mentality imbued with the pragmatic sense of art as well as of socially acknowledged rules, pretending - with a thespian skill - that he understands everything, even though in reality it is not the case at all. In the world where Mallarmé decides about the oncoming trends, where the press coverings are written by Jeana-Françoisa Lyotarda himself, the affair between Avantgarde and Pop reaches the bizarre denouement in an ironic image of the persecution of the lovers by the authentic sublimity; the lovers who sincerely want to reconcile the market strategies with an Avant-garde project focused on the representation of the present, yet unpresentable "now"7. The "now" strongly related to the understanding of the Modern in the contemporary commercial world:

Ser moderno en la era del mercado implica, como es sabido, debatirse entre la confianza en la novedad - tecnológica, artística - y la certidumbre de la capacidad que el mercado tiene para reapropiar en su favor los contenidos de la novedad. La respuesta avant-pop a esta problemática no será ya la de ignorar programáticamente / tolerar sociológicamente los productos de la baja cultura ni la de conservar museísticamente los objetos de la alta, sino la de teorizar sobre Los Simpson y descubrir las virtudes del Finnegans Wake en diagonal. En cuanto a la cuestión de la novedad, valga el dictum de Mark Amerika: "Mezcla de vanguardismo alquímico y formación de capital chamánica, el avant-pop no es tu típico movimiento literario". (Fernández Porta, 2007: 228).

[To be modern in the age of the market implies, as one perfectly knows, struggling between the certainty of the power of the innovation - both technological and artistic - and the confidence about the capacity of the market to reaproppiate the new contents to its own advantage. The answer of the avant-pop to this issue will not be an attempt to ignore programmatically / socially tolerate the products of low culture or to museally conserve the objects of the high culture, but theorize about The Simpsons and revealing the virtues of Finnegans Wake diagonally. As far as the issue of the novelty is concerned, it will be beneficial to cite the words by Mark Amerka: "The Mixture of the alchemic Avant-garde and the shamanistic formation: the avant-pop is not your typical literary movement" (Fernández Porta, 2007: 228)]

7 Fernández Porta alludes to the text by Jean-François Lyotard: The Sublime and the Avantgarde. Cf. Fernández Porta 2007: 227. 
Fernández Porta intercepted the notion of the avant-pop from Larry McCaffery who, in turn, took it from the title of an album by Lester Bowie, the trumpeter and the compositor who used to tease the old tunes with his new arrangements and recreations of the well-known melodies: Blueberry Hill and Crazy. McCaffery sensed that Bowie's strategy is similar to the one that could be seen in postmodern literature and that is the reason why he introduced it once and again in the works about the most experimental tendencies in literature at the time. By referring to the musical nomenclature, Eloy Fernández Porta has successfully shown that it makes it quite easy and more specific to notice the new tendencies in the narrative. The music criticism is put in the Polish newspaper on a back burner, respectively the ones about the reviews about cinema and the theatrical ones, even though it is usually busy with incessant experimenting with the sound, required by the moving whirl of the technical abilities. It is very easy to react quicker to the generating of the new names in music criticism and, therefore, it reacts much more rapidly to the necessity of creating the new notions and the revision of the existing ones, thus, gaining the credibility.

The notion of an avant-pop was also taken by Ronald Sukenick who saw in the avant-popesque current not only the literary movement, but also the special and cultural one, expressed par excellence by hyperfiction:

El texto concebido como agregación de fuentes, formas y registros, crítica a la vez que creación y forma vital más que producto cultural. La hiperficción sería así la forma contemporánea de la tradición retórica, que Sukenick contrapone a la tradición de la lógica en el siguiente sentido: si la segunda propone directrices, convicciones y razonamientos definidos, la primera es un catálogo de recursos, ideas oposicionales y modalidades de expresión. (Fernández Porta, 2007: 230-231)

[The text conceived as an aggregation of the sources, forms and registers turns critically at the same time as creation and a form a little bit more vital than culture. Serious hyperfiction would be here a contemporary form of the rhetorical tradition, confronted by Sukenick with the logical tradition in a sense that if the second one offers the directions, the convictions and the defined reasons, the first one constitutes a catalogue of the means, contrasting ideas and the modulations of expression. (Fernández Porta, 2007: 230-231)]

Thusly, the "avant-pop gesture" would be a manipulated exploitation of stimuli, information and values of the cultural and market spheres, which would be a cause to a subversively evoked transformation in both a market and an artistic context. The amended statement would be similar to a computer virus turning the society and its habits thoroughly inside out. A consequence of this way of thinking is Mark Amerika's 
cyberpunk theory according to which an interception of the subversive elements takes place through the internet, data media and all kinds of information technologies. It is to induce an origin of a new model of creation and creator:

[...] el proyecto de un gomi no sensei, un maestro de la basura que construye a partir de los deshechos de la cultura contemporánea, llenando su carrito con una mezcla heterogénea de restos del hipermercado pop, recogiendo la polifonía posmoderna, adorando la idea de indiferenciación, empollando un relato o quizá una novela entera en los confines de una sola unidad sintáctica, apelando a la unidad de atención de un mosquito. (Amerika, Olsen 1995: 14)

[the project gomi no sensei, the master of rubbish who creates on the basis of the waste of the contemporary culture, filling his trolley with the heterogeneous mixture of the leftovers from hypermarket of pop, collecting the postmodern polyphony, adoring the concept of indistinctiveness, fitting the story or maybe even a whole novel in the limits of one syntactic unit, referring to the attention span typical of a mosquito. (Amerika, Olsen 1995: 14)]

This description better reflects, nevertheless, the essence of the euphoric immersion in the consumptionist creative possibilities typical for "los poppies" while the subject afterpop is a trend exposing different values. When comparing a pop artist with an afterpop artist, Eloy Fernández Porta draws attention to a different - higher - degree of an artistic and a social self-awareness of the afterpop artists and their distinct values hierarchy. It seems that at least for now afterpop is considered a niche trend, still emancipating hence still in a development stage. It is conceivable, that - as time goes by - the afterpop will lose its intermedial freshness, multiplied piecemeal character and so actively built the theoretical superstructure - some critics even made it more distinctive by insisting that the "nocilleros" created more literary texts and less theoretical-essayist ones ${ }^{8}$. And although Fernández Porta does not consider himself a spokesman for the generation of Fernández Mallo, Loriga and Uribe, without a doubt he senses the expediency of their creative intentions - a formal pursuit of the cultural extraverbial spheres, presenting books in multimedial forms and joining them with a monodram happening, provocative playing the older against the newer tendencies as well as with experiments in relation to the plot and style. Even though afterpop is a bit more sublimed version of pop, it is

8 "Menos teoría, menos normativa y disciplina inglesa para los demás, y más novela" [Less theory, less indications and less of an English discipline for the others, more novels]. (Azancot 2010). 
concerned with blurring the boundaries between the 'poppy' culture and the high or quasi-high culture, it also serves as a standard in the increasing volume of texts overstepping the traditional genological borders and relying on referrals to different kinds of media and their products of varying levels of sophistication.

The translation of this concept to Polish circumstances in the face of a lack of local holistic interpretations of the tendencies in prose over the last decades would be - it appears - advantageous in many aspects: there are not many Polish prose writers, born mid=seventies, who would dare to formulate a synthetic statement taking all, or at least the majority, of the prosaic tendencies of the current generation of authors in their thirties. An exception to this may be Michał Witkowski's sketch-essay entitled Recycling (Notatki na marginesie twórczści własneji innych roczników siedemdziesiatych) (Witkowski 2010: 90-50). Reprinted in the collective volume Literatura polska 1989-2009. Przewodnik (2010) prepared by critics and writers connected to the 'Ha!art' circle, Witkowski's text does not constitute an angle, which can be perceived as anywhere near to complete: it is dated 2001, which limits the referenced texts and names mainly to the nineties - the first Polish decade of free market and free media. Therefore at the moment a recycling continuation is missing (Recycling bis?): just as broad and precise an analysis of the young prose of the second decade of XXI century, even more so that - although some of the traits of the young literature detailed by Witkowski have survived like for example exploiting the 'pop-fraction' assumptions and creating literature out of literature in various, more or less surprising configurations - there still emerge new tendencies, which situate themselves somewhat against Witkowski's hopes and expectations. In 2001, the author of Margot wrote:

Roczniki siedemdziesiąte przeprowadziły już dosyć sprawną i szybką akcję dekonstrukcji modelu mitograficznego, dlatego pisanie dalej utworów „podgryzających" mitografię, powieść inicjacyjną i nostalgiczną to wyważanie otwartych drzwi. Również ton został już dostatecznie obniżony, sprowadzony na ziemię. Ta pierwsza fala roczników siedemdziesiątych [...] odegrała rolę likwidatorską i mam nadzieję, że na tym się nie skończy. Bo oto po oczyszczeniu terenu otwierają się przed nami ogromne, wspaniałe perspektywy. Taki język, jaki sobie wywalczyliśmy, uwolnieni od konwencji mitograficznych i innych, otwiera nas na prawdziwa, jak najbardziej dzisiejszą rzeczywistość, tę "lodówkę na nóżkach", jak ją pozwoliłem sobie nazwać. Mam nadzieję, że przynajmniej niektórzy z nas opiszą ją świeżym, agresywnym językiem, bez min i manier konwencji, bez stylizowania, i nareszcie zechcą objaśnić, co się pod tą rzeczywistością kryje. (Witkowski 2010: 49-50) 
[Writers born in 1970's have carried out a rather dextrous and quick deconstruction of the mythographical model, that is why continuous writing of texts biting into mythography, an initiation and nostalgic novel is like reinventing the wheel. Also the tone has been sufficiently lowered, grounded. The first wave of these authors played a role of a liquidator and I hope it is not going to end there. Because here after clearing the ground the new, great perspectives have emerged. The language we have fought for, freed from mythographic and other conventions, is opening us to a real, contemporary reality, the 'fridge on feet', as I allowed myself to name. I hope, that at least some of us will describe it using a fresh, aggressive langauge, without any masks or convention mannerisms, without stylisation, and at last will explain what exactly this reality is. (Witkowski 2010: 49-50)]

How in the context of expectations of the author of Barbara Radziwittówna z Jaworzna-Szczakowej should we then treat - to mention at least one of the most famous and important names - much respected and prized creations of Ignacy Karpowicz, in which all types of myth and stylisation often play the role of a compositional-storyline leitmotif? Witkowski's analysis seems a cause, one of the original links of a description of what is technically new in literature, especially in prose. From time to time a statement appears from one of the published authors, like Lament miłośnika cegieł by Jacek Dukaj, in which - ironically - he expresses not a hope for crystallisation of the innovative tendencies but rather a yearning for a $19^{\text {th }}$ century realism, prosaic fullness and a coherently developed novel. Beside Przemysław Czapliński's Efekt bierności. Literatura w czasie normalnym (Kraków 2004) or Powrót centrali. Literatura w nowej rzeczywistości (Kraków 2007), nobody else proposes a structuring frame useful in interpreting what in the Polish prose in the context of media could actually be perceived as innovative. Maybe it is still influenced by Euro- and Polishcentric attitudes of the prosaics debuting in the last few decades - not many of them reach for texts that have not been yet translated and which are essential in the context of metaprosaic research in the world, like novels and the essays of David Foster Wallace, fashionable in the niche intellectual circles or fickle critical texts by Enrique Vila-Matas. Perhaps this is the reason why afterpop has not arrived in Poland yet. Especially that avant-pop which is - as we know - one of the pillars of afterpop, was not so long ago (in 2010) described by one of the Polish researchers as follows:

obecnie jeden z najpopularniejszych ruchów w sztuce zachodniej. Zrodzony na gruzach postmodernizmu jako mutacja cyberpunka największe triumfy święcił w latach dziewięćdziesiątych. Do Polski dociera z opóźnieniem, podobnie jak z opóźnieniem dotarły do nas elementy, które przyczyniły się do powstania avant-popu, czyli mass media i wysoko rozwinięta technologia. (Marecki 2010: 220) 
[Nowadays one of the most popular movements in the western art. Created from the remains of postmodernism as a mutation of cyberpunk it rode high in 1990's. It gets to Poland with a delay, just like with a delay reached here the elements, which were the cause of the emergence of avant pop, namely mass media nad highly developed technology. (Marecki 2010: 220)]

Notwithstanding the clear processual character of adapting the new aesthetics in Poland, Marecki also notices the influence and traits of avantpop in the works of a few young Polish fiction writers and artists, among others Sławomir Shuty, Wilhelm Sasnal and in the works of a duo Krasnowolski-Tkaczyk (cf. Marecki 2010: 221-225).

It seems that the situation with afterpop may be similar: the Polish authors do need a little bit more time to include in their creative act the possibilities offered by the new media in such a way that they bring their strategies beyond the level of literal references and mechanical copying of the styles present in non-literary communication situations. It is worth noting that the assessment of the potential dynamic accommodation of the afterpop creative approaches is difficult even in the case of such a dominant and resiliently evolving medium in Poland like the internet. Evident at the start of the first decade of $21^{\text {st }}$ century upheaval around the notion of "liternet" or "netart" seems to lose its power - whatever the case may be the hitherto new media are common today to such a degree that they are an integral element of Polish everyday life, whereas they do not bring many expected results in the cultural and artistic areas. In 2003, Marta Cuber stated perspicaciously in the symptomatically entitled text Internet jako źódło cierpień literatury. O polskiej prozie internetowej ( $i$ jednym dramacie) [Internet as a Source of Suffering for Literature. About the Polish Internet Prose (and one drama)]:

Polska proza internetowa (i jeden dramat) przypomina naiwne dziecko, które chciałoby zjeść cukierek i jednocześnie zatrzymać go w ręce. Teksty, jakie przeglądałam, starają się bowiem załatwić dwie sprawy nie do pogodzenia (przy ambitnych założeniach): zachować właściwości tradycyjnej literatury i, gdzie można (a raczej, gdzie wypada), błysnąć sieciowym nowatorstwem. W ten sposób jednak nie podobna zostać avant-garde. Poza wszystkim nie proponuje się w nich wiele ciekawego: zarówno na poziomie narracji, jak i fabuły. Nie chciałabym się bawić w prognozowanie, ale wreszcie będzie trzeba polskiemu liternetowi zjeść ten cukierek (przymierzania się do poważniejszej literatury internetowej, jeżeli tylko taka jest możliwa) i kupić nowe, to znaczy zaproponować garść bardziej interesujących pomysłów. Oczywiście, przy założeniu że proza internetowa zamierza rozszerzyć kanał komunikacyjny o czytelników Prousta, Joyce'a czy Llosy... Bo namawianie literatury popularnej (a na tym poziomie zatrzymuje się przynajmniej kilka wymienionych tekstów) do zakupu kolejnych torebek łakoci jest niekonieczne. (Cuber 2003: 92-93) 
[Polish internet prose (and one drama) reminds a naïve child who would like to eat a candy and hold it in its hand at the same time. The texts, which I reviewed, are trying to reconcile two issues that cannot be brought together successfully (while keeping an ambitious approach): to retain the characteristics of the traditional literature and, wherever possible (or rather, wherever befitting), show an internet-like innovation. If writing this way, it is not possible to become avant-garde. Moreover they have nothing interesting to offer: both on the level of narration as well as the storyline. I would not like to play a role of a forecaster, however it will eventually come to a point where the Polish liternet will have to eat this candy (while aspiring to a more serious internet literature, if it is at all possible) and buy new ones, which means proposing a few more interesting ideas. Obviously, it all is based on the assumption that the internet prose is going to widen the communication channel to the readers of Proust, Joyce or Llosa... Because persuading the popular literature (an at least a few of the mentioned texts never went beyond this level) to buy more bags of sweets is unnecessary. (Cuber 2003: 92-93)]

The works around which Cuber evolves her harsh evaluation of the Polish liternet, are Tabu by Kinga Dunin, Miłe fantazji poczatki by Sławomir Shuty (2001),Cz@t (drama) by Krzysztof Rudowski, S@motność w sieci (2002) by Janusz. L. Wiśniewski or created along with the internauts Krótka historia Iwony Tramp by Krystyna Kofta (2001). These titles have been present on the literary market for over ten years now, however they have never found many Polish liternet successors.

It seems that the Polish scene misses a young researcher of a sharp personality like Eloy Fernández Porta ${ }^{9}$, who by juggling daringly with the names of authors from a variety of cultural areas - noting the following as well: W.S. Burroughs, Julian Rios, David Cronenberg or, mentioned earlier, Haneke - and referring to their experiments, theories and intentions, based on principles but gracefully and wittingly defines where the meaning of the literary texts is situated in the panoramic depiction of the current culture. He is opposed to a preconceived and conventional interpreting of texts of young authors, through showing the pop qualities in the plots of the "serious" writers, supported by establishment, like Javier Marías and, at the same time, he focuses on the "afterpop" qualities, innovation in the "los nocilleros" novels, like the ones by Ray Loriga. It needs to be noted that this new formation gained the precious awareness that the literature, attacked from all over by the meaning-making impulses, flexible in relation to the philosophical, ethical, anthropological, theological and ideological concep-

9 Every publication of Fernándeza Porty posterior to the Afterpop... has been received with a great amount of interest, enthusiasm and applause from the critics. One of his recent works: $€ ® O$ \$. La superproducción de los afectos, another treatise-essay, in April 2010 was awarded with Premio Anagrama for the best essay of the year. 
tions - it does, indeed, according to Fernández Porta, become a place of the convergent media implosion, a continual osmosis and reinterpretation of the cultural and intellectual atoms, which together make the global cultural network. This awareness consecutively opens up incomparably vaster areas for (extra) literary and structural peregrinations.

\section{Bibliography}

Amerika Mark 2007, Meta/Data. A Digital Poetics, Cambridge, MA: The MIT Press.

Amerika Mark, Olsen Lance 1995: Smells like Avant-Pop: An Introduction, of Sorts, [in:] In Memoriam to Postmodernism, San Diego: San Diego State University Press, [in:] Fernández Porta Eloy 2007, Afterpop. La literatura de la implosión mediática, Córdoba: Editorial Berenice.

Azancot Nuria 2010, «Los fragmentarios, ¿a muerte con los clásicos? Los jóvenes nocilleros se enfrentan a las críticas generales de autores consagrados", El Cultural, 12.03.2010, http://www.elcultural.es/version_papel/LETRAS/26783/Los_fragmentarios_a_muerte_con_los_clasicos (28.05.2012).

Baricco Alessandro 2002, Next. Sobre la globalización y el mundo que viene, Spanish translation by X. González Rovira, Barcelona: Editorial Anagrama,

Cuber Marta 2003, Internet jako źródło cierpień literatury. O polskiej prozie internetowej (i jednym dramacie), [in:] Liternet.pl, ed. Piotr Marecki Cracow: Rabid.

Fernández Porta Eloy 2007, Afterpop. La literatura de la implosión mediática, Córdoba: Editorial Berenice.

Hopfinger Maryla 2010, Literatura i media. Po 1989 roku, Warsaw: Oficyna Wydawnicza.

Humanes Bespín Ivan 2007, “A mí me gusta hablar de qué actitudes pueden representar a autores distintos o distintos estados de ánimo del mismo autor". Interview with Eloy Fernández Porta, http://www.literaturas.com/v010/sec0707/entrevistas/entrevistas-02.html. (28.05.2012).

Kita Barbara 2003, Miedzy przestrzeniami. O kulturze nowych mediów, Cracow: Rabid.

Literatura polska 1989-2009. Przewodnik 2010, ed. P. Marecki, Cracow: Ha!art.

Marecki Piotr (ed.) 2003, Liternet.pl, Cracow: Rabid.

Marecki Piotr 2010, Avant-pop po polsku, [in:] Literatura polska 1989-2009. Przewodnik, ed. P. Marecki, Cracow: Ha!art.

McCaffery Larry (ed.) 1995, After Yesterday's Crash. The Avant-Pop Anthology, New York: Penguin.

Siwecki Piotr 2010, Optymizm warunkowy albo kilka tautologicznych uwag na temat literatury alternatywnej - avant-pop i banalizm jako strategie istnienia literatury w społeczeństwie spektaklu, [in:] Literatura polska 1989-2009. Przewodnik, ed. P. Marecki, Cracow: Ha!art.

Witkowski Michał 2010, Recycling (Notatki na marginesie twórczości własnej i innych roczników siedemdziesiatych), [in:] Literatura polska 1989-2009. Przewodnik, ed. P. Marecki, Cracow: Ha!art.

Wójtowicz Ewa 2008, net art, Cracow: Rabid. 